\title{
Standardization of Purified Extract Mahoni Seed and Antioxidant Activity
}

\author{
Virsa Handayani ${ }^{1}$, Ahmad Najib ${ }^{2}$, Rezki Amriati Syarif ${ }^{3}$, \\ Abdullah Mahmud $^{4}$, Nur Asha ${ }^{5}$, Aktsar Roskiana Ahmad ${ }^{6 *}$ \\ Laboratory of Pharmacognosy and Phytochemistry, Faculty of Pharmacy \\ Universitas Muslim Indonesia, Makassar Indonesia
}

\begin{abstract}
Indonesia has many plants that have been used for treating many diseases such as diabetic. One of the Indonesian plants has been shown the antidiabetic activity such as mahoni. In this study, we have investigated the standardization of the purified extract of the mahoni seeds and its antioxidant activity. The standardization methods include organoleptic test, determination of drying loss, determination of, total ash level, determination of acid-insoluble ash level, determination of water-soluble essence level, determination of ethanol soluble essence level, phytochemical profile test: alkaloid test, flavonoid test, phenolic test, saponin test, terpenoid, and steroid test. The results show the purified extract mahoni seed qualify as a raw material for herbal medicine and also has potential as an antioxidant $\mathrm{IC}_{50} 33.86 \mathrm{ug} / \mathrm{ml}$ that compare with the standard.
\end{abstract}

Keyword: antioxidant, standardization, Swietenia mahagoni (L.) Jacq, purified extract.

\section{Introduction}

Indonesia has many plants that have been used for treating many diseases such as diabetic. One of the Indonesian plants has been shown the antidiabetic activity namely Mahon (swietenia mahagoni (L.) Jacq). Previous reports have been reported mahoni as antidiabetic, anti-inflammation, anti-mutagenesis, antihypertension, anti-malaria, and anti tumors. Another researcher also was reported mahoni as an anti-diabetic, nevertheless not clear with the mechanism ${ }^{1,2}$. The major compound of the mahoni is switenine, however in seeds also contain a lot of lipids ${ }^{3}$. Switenine has been investigated to decrease cholesterol levels, triglycerides, and liver glycogen. The dose of the swietenine 25 and $50 \mathrm{mg} / \mathrm{kg}$ weight for 5 days could decrease the fasting blood glucose approximately $47,34 \mathrm{mg} / \mathrm{dL}$ and $55,85 \mathrm{mg} / \mathrm{dL}$, respectively ${ }^{4}$. In addition, mahoni seeds also have activity as an antioxidant. In this study, we have investigated the standardization of the purified extract of the mahoni seeds and its antioxidant activity. 


\section{Material and Method}

\section{Material}

Mahoni seeds. Dichloromethane (teknis), methanol (teknis), $n$-butanol (teknis), $n$-hexane (teknis), TLC plate (Merck cat. 1.05554, Jerman), TLC kit, the rotary evaporator (Buchi R-215, Jerman), spectrophotometer UV-Vis (Hitachi U 2000, Jepang). DPPH (Sigma, USA).

\section{Method}

\section{Extraction and purification}

The seeds of the $S$. mahagoni have been collected in Makassar. The specimens have identified in Laboratory Pharmacognosy and Phytochemistry UMI. The seeds have ground and ready to extract. To purify the extract from the lipid, we have used hexane solution. Furthermore, we extracted with ethanol solution.

\section{Standardization}

The purification extract has been standardized by following the protocol of the "Standarisasi Ekstrak Indonesia" $(2000)^{5}$ and Ahmad et al., 2014 . The measurement-includes organoleptic test, etermination of drying loss, the persistence of, total ash level, determination of acid-insoluble ash level, determination of water-soluble essence level, determination of ethanol soluble essence level, and phytochemical profile test (alkaloid test, flavonoid test, phenolic test, saponin test, terpenoid and steroid test) ${ }^{6}$.

\section{Determination of Flavonoids content}

The purified extract $10 \mathrm{mg}$ has been measured with various concentration of $20 \mathrm{ppm}, 30 \mathrm{ppm}, 40$ ppm, $50 \mathrm{ppm}$, and $60 \mathrm{ppm}$. The each standard solution $(1 \mathrm{~mL})$ was added with $0.2 \mathrm{~mL} \mathrm{AlCl} \mathrm{10 \% ,} 0.2 \mathrm{~mL}$ potassium acetate $1 \mathrm{M}, 3.0 \mathrm{~mL}$ methanol and $5.6 \mathrm{~mL}$ aqua bidestillata, and then incubated for 30 minutes. Furthermore, absorbance was measured at a maximum wavelength of $415 \mathrm{~nm}^{7}$.

\section{Antioxidant activity}

The purified extract has been tested by using DPPH method. The extract with the various concentration. As much as $0.5 \mathrm{ml}$ sample added $3.5 \mathrm{ml}$ DPPH, thus incubated for 30 minutes. The DDPH has been detected by using Spectrophotometer UV-Vis at wavelength $570 \mathrm{~nm}$. The positive control used quercetin. The inhibition of the antioxidant has calculated with a linear curve ${ }^{8}$.

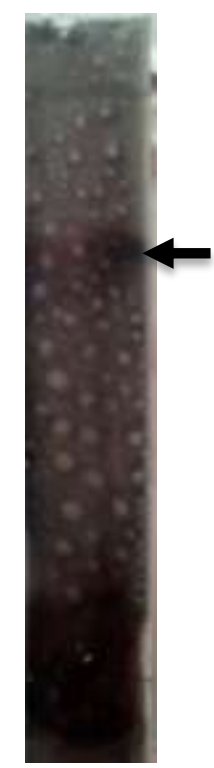

Figure 1. TLC profile of switenine. Stationary phase: silica gel F254 $(7 \times 1 \mathrm{~cm})$ plate, mobile phase :chloroform : methanol (1:1). (a) Before spraying, (b) Detection with Vanillin-sulphate acid reagent. 


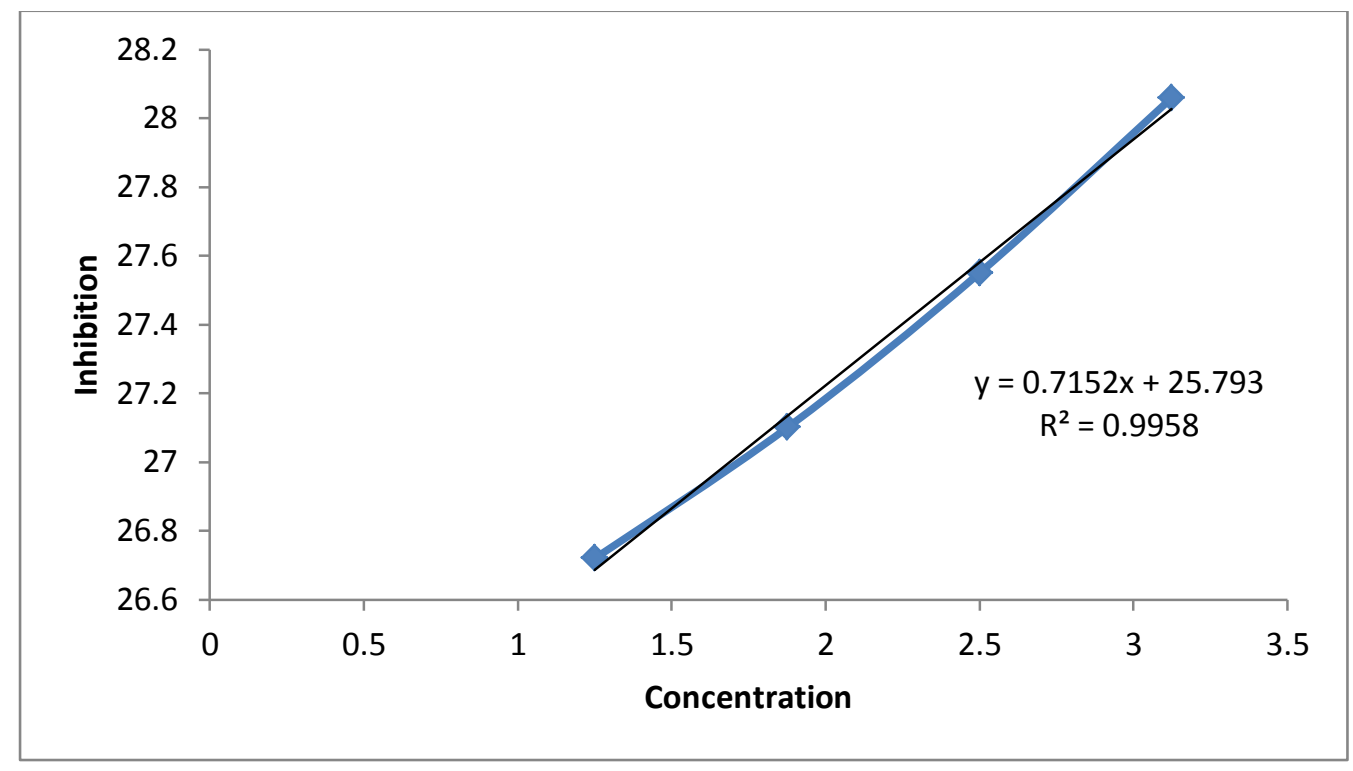

Figure 3. Antioxidant activity of the purified extract mahoni seed.

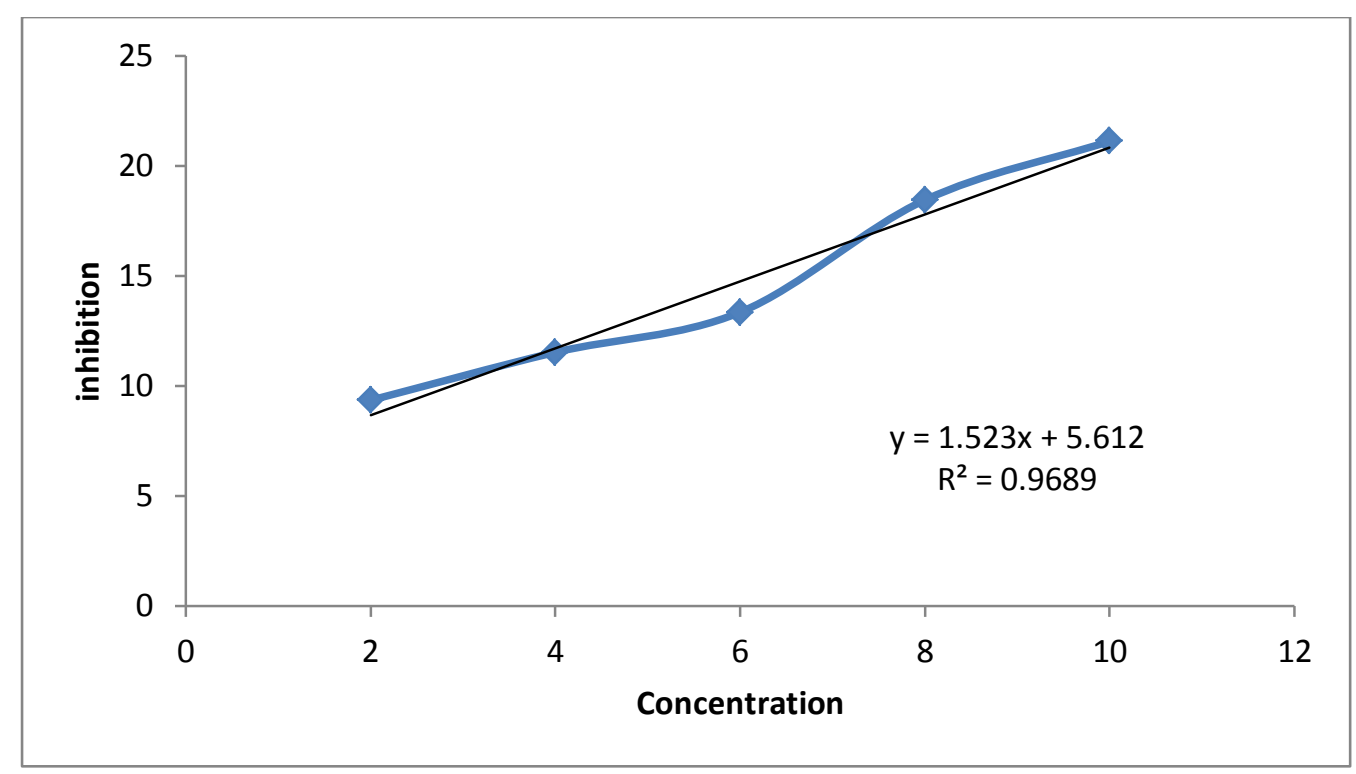

Figure 2. Antioxidant activity of the standard quercetin.

\section{Results and Discussions}

The standardization parametric according to Farmakope Herbal Indonesia (FHI) and Parameter Ekstrak Indonesia include organoleptic test, determination of drying loss, determination of, total ash level, determination of acid-insoluble ash level, determination of water-soluble essence level, determination of ethanol soluble essence level, phytochemical profile test: alkaloid test, flavonoid test, phenolic test, saponin test, terpenoid and steroid test. (Table 1).

In this experiment amount, $3750 \mathrm{~g}$ was extracted and got the purified extract about $73.86 \mathrm{~g}$ or $1.9 \%$

The standardization was investigated include the parametric of standardization, metal contaminant, and microbiology test. In the organoleptic test, the extract has a red-brown color and bitter taste (Table 2). The determination of total ash level was not more than $1.71 \%$ with acid insoluble not more than $0.38 \%$, the result showed to consist of an inorganic compound, but lower than $2 \%$. The water-soluble level was not more 
than $14.84 \%$, and ethanol soluble was not more than $15.38 \%$. The results of phytochemical screening showed that the extract contains a few compounds such as a flavonoid, sapiens, terpenoid, and alkaloid (Table 2).

The metal contamination test aimed to observe the presence of a metal compound in the extract which intolerable in drug compounds such as $\mathrm{Pb}$ and $\mathrm{Cd}$. From the result of the test, it was found that contains the $\mathrm{Pb}$ and $\mathrm{Cd}$ but in the low concentration (tolerable). It was caused by the contamination of air pollution where the plant was growing (Table 3).

The important material for herbal medicine does not contain the microorganism. From the result have been shown the extract can be tolerable the microorganism (Table 4).

A purified extract of mahoni seeds has been detected for total flavonoid by using spectrophotometer UV-Vis and Rutin as standard ${ }^{9}$. That result showed contain 2,3ug/g extract (Table 5). The swietenine is the major compound of the mahonee seed. The extract has been applied in the TLC plate, evaluated by using chloroform: methanol (1:1) and can separate the swietenine compounds with the rate of flow value approximately 0.21-0.9 (Suliman, 2017) ${ }^{11}$. In this result, the spot is shown in the Rf about 0.773 and also has been detection by Vanillin-sulphate acid. Furthermore, the compound identified by using Image J. Then the result in $10 \mathrm{ul}$ extract solution contains about $2.49 \mathrm{ug} / \mathrm{ul}$ swieteni.

The Swietenia mahagoni extract (methanolic extract) has been shown the significant hypoglycemic and antioxidant activity in diabetic rats ${ }^{10}$. The purified extract has been tested with antioxidant assay by using scavenging DPPH method. The purified extract has $\mathrm{IC}_{50} 33.86 \mathrm{ug} / \mathrm{ml}$ (Table 6) and $29.14 \mathrm{ug} / \mathrm{ml}$ (Table 7) for quercetin as a standard. The results show that purified extract has activity as an antioxidant by the mechanism scavenging free radical.

Table 1. Extract rendamen

\begin{tabular}{cccc}
\hline Dried sample (g) & $\begin{array}{c}\text { Crude Extract } \\
(\mathbf{g})\end{array}$ & $\begin{array}{c}\text { Purified extract } \\
(\boldsymbol{\%})\end{array}$ & $\begin{array}{c}\text { Rendamen } \\
(\boldsymbol{\%})\end{array}$ \\
\hline $\mathbf{3 7 5 0}$ & 218.59 & 73.89 & 1.97 \\
\hline
\end{tabular}

Table 2. Standardization parameters

\begin{tabular}{ll}
\hline \multicolumn{1}{c}{ Test } & Result \\
\hline Organoleptic Test & Taste: Bitter \\
& Colour: Red-brown \\
Determination of drying losses & Not more than $0.22 \%$ \\
Total ash level & Not more than $1.71 \%$ \\
Acid-Insoluble ash level & Not more than $0.38 \%$ \\
Water-soluble essence level & Not less than $14.84 \%$ \\
Ethanol-soluble essence level & Not less than $15.38 \%$ \\
Phytochemical screening & (chemical \\
compound) & Essential oil $(-)$ \\
& Flavonoid $(+)$ \\
& Saponin $(+)$ \\
& Terpenoid $(+)$ \\
\hline
\end{tabular}

Table 3. Metal contamination test

\begin{tabular}{lcc}
\hline Parameter & Unit & Result \\
\hline Timbal $(\mathbf{P b})$ & ug/g & 0,0607 \\
Kadmium $(\mathbf{C d})$ & ug/g & $<0,003$ \\
\hline
\end{tabular}


Table 4. Microbiology test

\begin{tabular}{|c|c|c|c|c|c|}
\hline \multirow[b]{2}{*}{ ALT Bacteria } & \multicolumn{5}{|c|}{ Concentration } \\
\hline & $10^{-1}$ & $10^{-2}$ & $10^{-3}$ & $10^{-4}$ & $10^{-5}$ \\
\hline Purified mahoni seed & 10 & 3 & 3 & 3 & 1 \\
\hline ALT Fungi & $10^{-1}$ & $10^{-2}$ & $\begin{array}{c}\text { cent } \\
10^{-3}\end{array}$ & $10^{-4}$ & $10^{-5}$ \\
\hline Purified mahoni seed & 4 & 3 & 3 & 1 & 0 \\
\hline
\end{tabular}

Table 5. Flavanoid total

\begin{tabular}{ccccc}
\hline $\begin{array}{c}\text { Abs } \\
(\mathbf{Y})\end{array}$ & $\begin{array}{c}\text { Flavonoid } \\
\text { total (mg/L) }\end{array}$ & $\begin{array}{c}\text { Flavonoid content } \\
\text { (gr RE/ gram) }\end{array}$ & $\begin{array}{c}\text { Flavonoid content } \\
\text { (gram RE/ gram) }\end{array}$ & \% Flavonoid content \\
\hline 0,163 & 46,615 & 2,33 & & 0,233 \\
0,161 & 45,846 & 2,29 & 2,33 & \\
0,165 & 47,384 & 2,36 & & \\
\hline
\end{tabular}

Table 6. Antioxidant assay

\begin{tabular}{ccccc}
\hline Sample & $\begin{array}{c}\text { Concentration } \\
(\mathrm{ppm})\end{array}$ & Absorbance & Scavenging (\%) & $\mathrm{IC}_{50}$ \\
\hline Blank & & 0.784 & - & - \\
Purified mahoni & 20 & 0.365 & 53.44 & 33.86 \\
seed & 30 & 0.359 & 54.2 & \\
& 40 & 0.352 & 55.1 & \\
& 50 & 0.344 & 56.12 & \\
& $\mathrm{y}=0.7152 \mathrm{x}+25.793$ & $\mathrm{R}^{2}=0.995$ & \\
\hline
\end{tabular}

Table 7. Antioxidant activity of the standard (quercetin)

\begin{tabular}{ccccc}
\hline & $\begin{array}{c}\text { Concentration } \\
(\mathbf{p p m})\end{array}$ & Absorbance & Scavenging (\%) & $\mathbf{I C}_{\mathbf{5 0}}$ \\
\hline Blank & 30 & 0.824 & - & - \\
Quercetin & 2 & 0.747 & 9.34 & 29.145 \\
& 4 & 0.729 & 11.52 & \\
6 & 0.714 & 13.34 & \\
8 & 0.672 & 18.44 & \\
& 10 & 0.650 & 21.11 & \\
& $\mathrm{y}=1.523 \mathrm{x}+5.612$ & & $\mathrm{R}^{2}=0.9689$ & \\
\hline
\end{tabular}


Table 8. Antioxidant assay

\begin{tabular}{ccccc}
\hline Sample & Concentration (ppm) & Absorbance & Inhibition (\%) & IC $_{\mathbf{5 0}}$ \\
\hline Purified mahoni & 20 & 0.365 & 53.44 & 33.86 \\
seed & 30 & 0.359 & 54.2 & \\
\multirow{3}{*}{ Quercetin } & 40 & 0.352 & 55.1 & \\
& 50 & 0.344 & 56.12 & \\
& 2 & 0.747 & 9.34 & \\
& 4 & 0.729 & 11.52 & \\
& 6 & 0.714 & 13.34 & \\
& 10 & 0.672 & 18.44 & \\
\hline
\end{tabular}

\section{Conclusions}

The purified extract mahoni seed qualify as a raw material for herbal medicine and also has potential as an antioxidant $\mathrm{IC}_{50} 33.86 \mathrm{ug} / \mathrm{ml}$.

\section{Acknowledgment} 2018.

We would like thank to KEMENRISTEKDIKTI for supporting through Hibah Fundamental grant

\section{References}

1. Bera, T. K., Chatterjee, K., Jana, K., Ali, K. M., De, D., Maiti, S., \& Ghosh, D. (2012). Antihyperglycemic and antioxidative effect of hydro - methanolic (2:3) extract of the seed of Swietenia mahagoni (L.) Jacq. in streptozotocin-induced diabetic male albino rat: An approach through pancreas. Genomic Medicine, Biomarkers, and Health Sciences, 4(4), 107-117. doi:10.1016/j.gmbhs.2012.11.001, doi:10.1016/j.gmbhs.2012.11.001.

2. Naima, J., , N. M. P., , M. R. I., , J. A., Papel, , M. M. R., \& Hossain, a. M. K. (2017). Isolation of Nontoxic Fraction from Swietenia Mahagoni Seed and its Hypoglycemic Activity in Normal and Diabetic Rats. Journal of Chemical and Pharmaceutical Research, 9(10), 176-181.

3. De, D., Chatterjee, K., Ali, K. M., Bera, T. K., \& Ghosh, D. (2011). Antidiabetic Potentiality of the Aqueous-Methanolic Extract of Seed of Swietenia mahagoni (L.) Jacq. in Streptozotocin-Induced Diabetic Male Albino Rat: A Correlative and Evidence-Based Approach with Antioxidative and Antihyperlipidemic Activities. Evidence-Based Complementary and Alternative Medicine, 2011, 892807. doi:10.1155/2011/892807

4. Dewanjee, S., Maiti, A., Das, A. K., Mandal, S. C., \& Dey, S. P. (2009). Swietenine: a potential oral hypoglycemic from Swietenia macrophylla seed. Fitoterapia, 80(4), 249-251. doi:10.1016/j.fitote.2009.02.004, doi:10.1016/j.fitote.2009.02.004.

5. Depkes Republik Indonesia. Parameter Standard Umum Pembuatan Ekstrak Tumbuhan Obat.Jakarta, 2000.

6. Aktsar Roskiana Ahmad, A. A. D., Rachmat Kosman. (2014). Standardization of simplisia and methanolic extract of cemba (Acacia rugata (lam.) fawc. rendle) leaves endemic plant from Massenrenpulu regency of enrekang. World Journal of Pharmaceutical Sciences, 2(12), 1808-1812

7. Hamidu, L., Ahmad, A. R., \& Najib, A. (2017). Qualitative and Quantitative Test of Total Flavonoid Buni Fruit (Antidesma bunius (L.) Spreng) with UV-Vis Spectrophotometry Method. Pharmacognosy Journal, 10(1), 60-63. doi:10.5530/pj.2018.1.12, doi:10.5530/pj.2018.1.12. 
8. Ahmad, A. R., Elya, B., \& Mun'im, A. (2017). Antioxidant Activity and Isolation of Xanthine Oxidase Inhibitor from Ruellia tuberosa L. Leaves. Pharmacognosy Journal, 9(5), 607-610. doi:10.5530/pj.2017.5.96

9. Abd. Malik, A. R. A. (2014). Determination of Phenolic and Flavonoid Contents of Ethanolic Extract of Kanunang Leaves (Cordia myxa L.). International Journal of PharmTech Research, 7(2), 243-246.

10. Panda, S. P., Haldar, P. K., Bera, S., Adhikary, S., \& Kandar, C. C. (2010). Antidiabetic and antioxidant activity of Swietenia mahagoni in streptozotocin-induced diabetic rats. Pharmaceutical Biology, 48(9), 974-979. doi:10.3109/13880200903390051

11. Suliman, M. B. (2017). Preliminary Phytochemical Screening and Thin Layer Chromatography Analysis of Swietenia Macrophylla King Methanol Extracts. Chemistry of Advanced Materials, 3(1), 1-7.

12. Depkes Republik Indonesia, Farmakope Herbal Indonesia :Edisi I, Jakarta, 2008. 